\title{
Lean Technologies Application as a Tool to Increase the Economic Efficiency of the Production System
}

\author{
V. B. Elagina \\ Chair of Governance and Law \\ Volga state univercity of technology \\ Yoshkar-Ola, Russia \\ ElaginaVB@volgatech.net \\ O.A. Vasilkova \\ Chair of Governance and Law \\ Volga state univercity of technology \\ Yoshkar-Ola, Russia
}

\author{
G. R. Tsareva \\ Chair of Governance and Law \\ Volga state univercity of technology \\ Yoshkar-Ola, Russia \\ TsarevaGR@volgatech.net \\ N.A. Viktorova \\ Chair of Governance and Law \\ Volga state univercity of technology \\ Yoshkar-Ola, Russia
}

\begin{abstract}
The modern management system assumes that all enterprises striving to reach a positive economic trajectory must ensure high level of quality and product competitiveness, simultaneously losing their identification and reducing aspects that do not create any value for their customers. Using the example of the large production system of the Republic of Mari $\mathrm{El}$, in the framework of system, process and normative methodological approaches, the conditions and principles of lean technologies application and the appreciation of operations performed on the basis of continuous improvement were determined. Within the framework of the kaizen projects implemented at the enterprise, the types of economic effects obtained were defined, their scale was assessed, and the associated risks were identified in the context of the PDCA cycle. The need for improving the mechanism of transmitting information signals in order to reduce transaction costs was established.
\end{abstract}

Keywords: lean technologies, the principle of constant improvement, transaction costs, economic efficiency

\section{INTRODUCTION}

The successful activity of an enterprise in competitive environment implies constant improvement of manufacturing processes, product value reduction, and the product quality increase to meet not only current, but also future customer demands. The implementation of these activities does not necessarily involves an active investment policy, as it can be implemented by introducing lean production methods at the enterprise with consideration to the trends of the current stage of innovative development.

Lean manufacturing technology is the concept of customer satisfaction increase aimed at eliminating waste, boosting the efficiency and the effectiveness of manufacturing operations, enhancing management processes to respond immediately to environment changes.

The stakeholders in the framework of this concept are not only the consumers and the employees of the organization, but also the suppliers and the society as a whole experiencing the economic benefit.

In order to increase the competitiveness of its products and to improve business processes, the organization should have an innovative development strategy involving costs decrease by means of lean technologies. However, the implementation of lean technologies and the identification of reserves for reducing waste in the process of increasing the competitiveness of the enterprise, taking into account its innovative development, are still insufficiently studied.

\section{LiterATURE REVIEW AND RESEARCH METHODS}

According to the actual technical standard [1], the major lean manufacturing methods include the method of Work Environment Organization (the 5S System), Standard Work, Value Stream Mapping (VSM), Visualization, Single-Minute Exchange of Dies (SMED), Error Proofing (Poka-Yoke), Kanban (Pull System), as well as Total Productive Maintenance (TPM). However, in the study [2] they are classified as lean production tools. In our study we will hold to the approach proposed in [1].

The majority of studies focuses on lean technologies implementation. Both foreign researchers, for example, I. Masaaki [3], T. Ohno [4], M. Wader [5] and domestic ones have investigated the case study and the development of this aspect of manufacturing system improvement using the example of such large industrial enterprises as KAMAZ Publicly Traded Company (KAMAZ PTC), GAS Group 
innovation development that, in its turn, requires the organization of work to ensure a high level of competitiveness.

The output of competitive products in high-tech manufacturing often can be material-intensive and cost demanding. The majority of share in the base cost of such products is the cost of implementing the technological process in the imperfect manufacturing organization environment, characterized by excessive stocks of product and component inventory, expectations of parts process, great loss due to irrational movement of workers and objects of labor, manufacturing of defective products, and other features.

The consequences of this kind of loss, the so-called muda, are the decrease of production efficiency and product quality, the reduction of profits, and the worsening of enterprise economic conditions, that will entail the decrease of the organization's competitiveness in future.

The implementation of lean technologies aimed at reducing all types of losses, optimizing the flow of production process and ensuring its quality, has become the most acceptable and cost effective solution to this problem.

The company has been successfully implementing lean manufacturing techniques for more than six years. These are:

- Standard Work;

- Visualization;

- Work Environment Organization (The 5S System);

- Value Stream Mapping (VSM);

- Total Productive Maintenance (TPM).

The implementation of the lean manufacturing system at the enterprise takes a long period of time and requires a gradual reorganization of manufacturing. Therefore, it is more efficient to start transformational changes from separate production sites (Gemba). This approach was implemented at JSC Semi-Conductor Fabrication Plant.

The result of lean technologies application is the organization of an effective manufacturing system having minimal losses of the essential cost elements that determine the base cost of production with a concomitant increase of product quality.

In addition, the work for assessing the cost effectiveness of the measures taken is actively being carried out. The performance indicator based on the number of improvement suggestions by the average number of employees was 0.65 which allows to conclude about the potential growth capability of this value within the framework of eliminating the nonutilized human potential, one of the wastes classified of lean production [16]. The indicated value shows sufficient funds for the further lean application subject to correct quality management and positive financial and economic results achievement.

As part of the innovation strategy implementation the company has purchased the up-to-date technological equipment and has developed an innovative infrastructure; and civilian products within the framework of the strategy of 
calculated on the basis of the current process mapping or the management accounting data.

The costs after the implementation are estimated as planned from the future value stream mapping or the actual utilization of resources after the implementation process. Improvement costs include energy, materials, labor, and other costs.

JSC Semi-Conductor Fabrication Plant has developed process flow maps, Regulations for the incentives of employees, forms of suggestions submitted, and other documents of the quality management system.

The following courses are implemented to involve personnel in the process of continuous improvement in the manufacturing system:

1. The submission of improvement suggestions, the socalled individual kaizen. Thus, 491 improvement suggestions were submitted at the enterprise under study from 2014 to $2018,83 \%$ of them were accepted, $64 \%$ of all projects submitted to consideration were implemented, the employees' productivity increased by $43 \%$, and the total economic effect exceeded 3 million rubles.

\section{Projections - group kaizen - team work.}

Consider the implementation effectiveness of the team project realization on the change of glass tables to polyurethane plates at the production site manufacturing circuit boards of the 5th type product. The effects from this realization are the following: tools save by increasing the durability of the knives, save on the table material change, the quantity reduction of the manufacturing defect 'short circuit' from $9 \%$ to $4.2 \%$, and cost savings related to the workers' idle time owing to knives change. The project implementation allowed the company to save more than 3.6 million rubles a year.

3. Efficiency suggestions - management kaizen, involving the technical creativity incentive.

Thus, the economic effect of the submitted suggestion to optimize the burning kiln charge, comprising energy save, labor compensation and kiln furniture, amounted to almost 650 thousand rubles.

The reward rate for efficient suggestions directly depends on the economic effect, it should not be less than 700 rubles and more than 100,000 rubles.

\section{DISCUSSIONS}

When implementing lean technologies on the basis of the principle of continuous improvement, there is a question of the decision-making advisability on the accepting of a particular method or suggestion for improvement aimed at the waste elimination.

The decision mostly depends on the complexity of this proposal implementation and the expected economic effect. The implementation complexity includes the specifics of the process flow and the personnel qualification needed to implement the submitted suggestion. the costs before the measures implementation, the costs after the processes improvement, and the cost of its implementation. The costs before the implementation are
The economic effect of improvements in lean technologies obtained.

The economic effect is estimated as the difference between 
The cost effectiveness assessment of the lean production projection should occur sequentially at the stages of its implementation [17].

Using the example of [18] consider the emerging economic effects of kaizen improvements in the context of the Deming cycle of continuous improvement or "plan-docheck-act" (PDCA) with the concept of risk management application (Table I).

\section{TABLE I. EFFECT AND RISKS OF LEAN MANUFACTURING IN} THE CONTEXT OF PDCA

\begin{tabular}{|c|c|c|}
\hline Phase & Economic effect & Types of risks \\
\hline Plan & $\begin{array}{l}\text { Potential (preliminary } \\
\text { economic effect based } \\
\text { on predictive } \\
\text { improvements } \\
\text { characteristics) }\end{array}$ & $\begin{array}{l}\text { Poor work organization } \\
\text { and process control; } \\
\text { Lack of experience and } \\
\text { qualification of the } \\
\text { developers } \\
\text { improvement projects; } \\
\text { Lack of data collection; } \\
\text { Disorder of information } \\
\text { flows. }\end{array}$ \\
\hline Do & $\begin{array}{l}\text { Expected } \\
\text { effect due } \\
\text { implementation to } \\
\text { permanent save; } \\
\text { depending offect, } \\
\text { number of output } \\
\text { products; operating } \\
\text { costs save not related to } \\
\text { product release) }\end{array}$ & $\begin{array}{l}\text { Poor employees' } \\
\text { qualification and skill } \\
\text { level; } \\
\text { Staffing Change; } \\
\text { Personnel resistance; } \\
\text { Financing gap; } \\
\text { Equipment failure; } \\
\text { Deviation from work } \\
\text { completion deadlines. }\end{array}$ \\
\hline Check & $\begin{array}{l}\text { Actual - is analyzed and } \\
\text { evaluated through the } \\
\text { improvement (state } \\
\text { change) of the process, } \\
\text { the improvement degree } \\
\text { for the selected period } \\
\text { according to the main } \\
\text { characteristics - quality, } \\
\text { time, costs. }\end{array}$ & $\begin{array}{l}\text { Lack of data collection; } \\
\text { Disorder of information } \\
\text { flows; } \\
\text { Poor skill level of the } \\
\text { controlling unit. }\end{array}$ \\
\hline Act & $\begin{array}{l}\text { The subsequent } \\
\text { economic effect } \\
\text { obtained and evaluated } \\
\text { after the improvement } \\
\text { implementation }\end{array}$ & $\begin{array}{l}\text { Disorder of information } \\
\text { flows; } \\
\text { Changes in company } \\
\text { policy. }\end{array}$ \\
\hline
\end{tabular}

All of the above risks can be grouped as follows:

1) organizational risks: poor work organization and process control, changes in company policy, and others;

2) financial risks: financing gap or maldistribution of finances;

3) manufacturing risks: equipment failure, deviation from work completion deadlines, and others;

4) personnel risks: lack of experience and qualification of the developers of improvement projects, poor employees' qualification and skill level, staffing change;

5) informational risks: disorder of information flows, lack of data collection.

As can be seen in Table I, the predominant risks at all stages of the continuous improvement cycle are the risks related to the disorder of information transmission leading to its asymmetry, databases uncertainty, the so-called transaction costs in this survey.

Transaction costs mean employees' interaction in the process of lean technologies implementing that cause the waste of time and resources [2]. Accordingly, their reduction will contribute to the economic efficiency increase of measures taken in lean manufacturing system. The need to optimize transaction costs through the implementation of innovative tools in the framework of lean manufacturing is also underlined in the study [19].

According to the size of an enterprise, I. D. Kotliarov [20] proposes to establish centers for the regulation of transaction costs reducing either at the enterprise or using outsourcing.

The elimination of the uncertainties between the subjects of lean technologies is considered to be a measure to reduce transaction costs. This can be achieved by means of developing tactical plans for the activities implemented, appointing responsible persons, developing standardized operational processes for implementing kaizen projects, overcoming the disruption of the information transmission from ordinary employees to senior staff, eliminating the insufficiency and inaccuracy of the data collection by organizing balanced flows of information reports transfer between departments by organizing the account, analysis, and evaluation of costs for product quality.

\section{CONCLUSION}

The implementation of lean technologies allows to achieve significant improvements in both economic and production performances and to eliminate waste without regard to the application field. The benefits depend on the degree of adaptation of both the organization and its employees to the changing conditions of the internal and external environment. The personnel engagement, one of the principles of quality management, is mainly developed by socio-psychological and material incentives.

The findings of this study have indicated significant improvements in the lead time and productivity of some technological operations.

The economic effect of lean technologies implementation should be evaluated periodically and gradually that allow to make the necessary corrections within the continuous improvement cycle. Moreover, the results of this implementation enable to assess the most profitable improvement ways for the enterprise at the whole manufacturing system level.

Having regard to the above data as well as taking into account the consumer requirements for manufactured products it becomes possible to increase the economic strength of the organization and to identify the potential ways of its innovative development through the further application of lean production methods. 
Case of a brandable company in Johannesburg, South Africa", Proceedings of the International Conference on Industrial Engineering and Operations Management, 2019, vol. 2019, issue MAR, pp. 13931399.

[1] "State Standard 56407-2015. Lean production", Basic methods and tools Moscow: Standartinform, 2015, $20 \mathrm{p}$.

[2] "State Standard 56020-2014. Lean production", Fundamentals and vocabulary Moscow: Standartinform, 2015, $15 \mathrm{p}$

[3] Kaizen I. Masaaki, "The Key To Japan's Competitive Success", Moscow: Alpina Publisher, 2012, 274 p.

[4] T. Ohno, "Toyota production system: Beyond large-scale production", Moscow, 2005, $192 \mathrm{p}$.

[5] M. Wader, "Lean Tools: A pocket Guide to implementing lean practices", Moscow: Alpina Publisher, 2012, 125 p.

[6] S. G. Kreneva, E. N. Halturina, T. B. Bakhtina, G. R. Tsarev, and V. B. Yelagina, "Improving the Efficiency of Agricultural Enterprises on the Basis of Lean Manufacturing Tools Adaptation in the Republic of Mari El", International Journal of Economic Perspectives, 2016, vol. 2, pp.271-281.

[7] S. Solaimani, A. Haghighi Talab, and B. van der Rhee, "An integrative view on Lean innovation management", Journal of Business Research, 2019, vol. 105, pp. 109-120.

[8] L. K. Yik and J. F. Chin, "Application of 5S and Visual Management to Improve Shipment Preparation of Finished Goods", IOP Conference Series: Materials Science and Engineering, 2019, vol. 530 (1), no. 012039.

[9] M. Jimenez, L. Romero, J. Fernandez, M. M. Espinosa, and M. Domínguez, "Extension of the Lean 5S methodology to 6S with an additional layer to ensure occupational safety and health levels", Sustainability (Switzerland), 2019, vol. 11 (14), no. 3827.

[10] S. Kurpjuweit, D.Reinerth, C. G. Schmidt, and S. M. Wagner, "Implementing visual management for continuous improvement: barriers, success factors and best practices", International Journal of Production Research, 2019, vol. 57, issue 17, pp. 5574-5588.

[11] S. C. Mukwakungu and M. D. Mabasa, "Lean techniques application to improve product replacement process in a manufacturing organization:
[12] T. N. Issa, "Lean manufacturing implementation in fused plastic bags industry", ACM International Conference Proceeding Series, 10th International Conference on Information Management and Engineering, ICIME 2018, 2018, pp. 151-158.

[13] V. Shivajee, R. K. Singh, and S. Rastogi, "Manufacturing conversion no. 117678 .

[14] M. O. Vieira and R. B. Lopes, "Improving production systems with lean: A case study in a medium-sized manufacturer", International Journal of Industrial and Systems Engineering, 2019, vol. 33, issue 2, pp. 162-180.

[15] T.-L Nguyen, "STEAM-ME: A Novel Model for Successful Kaizen Implementation and Sustainable Performance of SMEs in Vietnam", Complexity, 2019, vol. 2019, no. 6048195.

[16] V. B. Elagina, M. E. Malinkin, and S. P. Stukov, "Use of the principles of lean production for quality achievement and competitiveness of products", Herald of the Belgorod University of Cooperation, Economics and Law, 2019, vol. 3, pp. 77-86.

[17] K. P. Fuller, S. A. Ovchinnikov, and I. V. Emanakov, "Evaluation of the implementation efficiency of lean production", Quality management methods, 2016, vol. 9, pp. 13-15.

[18] N. V. Merzlikina, V. S. Sekatsky, K. O. Poleshchuk, L. D. Deduh, and K. O. Oskolkova, "Qualigram as a description tool of processes accounting the pdca cycle and risk-oriented thinking", International research journal, 2017, vol. 11(65), issue 4, pp. 55-58.

[19] S. V. Iudina, M. S. Garifullina, and N. V. Serikova, "Trends in Development of Corporate Organizational and Managerial Innovations in Russia and the Principles of Lean Production", Mediterranean Journal of Social Sciences, 2015, vol. 6, issue 3, pp. 492-498.

[20] I. D. Kotliarov, "Transaction cost and activity of economic agents", Journal of Institutional Studies, 2017, vol. 9, issue 1, pp.70-87.. cost reduction using quality control tools and digitization of real-time data", Journal of Cleaner Production, 10 November 2019, vol. 237, 